\title{
An insider's take on practising medicine in the US
}

\author{
The Color of Atmosphere: One Doctor's \\ Journey In and Out of Medicine \\ Maggie Kozel MD \\ Chelsea Green Publishing; 2011
}

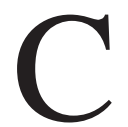

anadian medicine has a complex relationship with medicine in the United States. Differences in policy, philosophy, accessibility and funding are often raised in discussions on both sides of the border, and the question of which system is superior has been debated by politicians and the press for years.

For physicians, there are also personal questions. What would it be like to work in the American system? Would I make more money? Would I have better access to resources for my patients? What about dealing with private insurance companies? It is one thing to read statistics and expert opinions of medical leaders, but sometimes it's a story we want to hear, the experience of an average doctor. One such story is that of Dr. Maggie Kozel, author of The Color of Atmosphere: One Doctor's Journey In and Out of Medicine.

In this book, Kozel recounts the story of her training as a pediatrician, her early years of practice as a civilian doctor with the US Military, and her later years

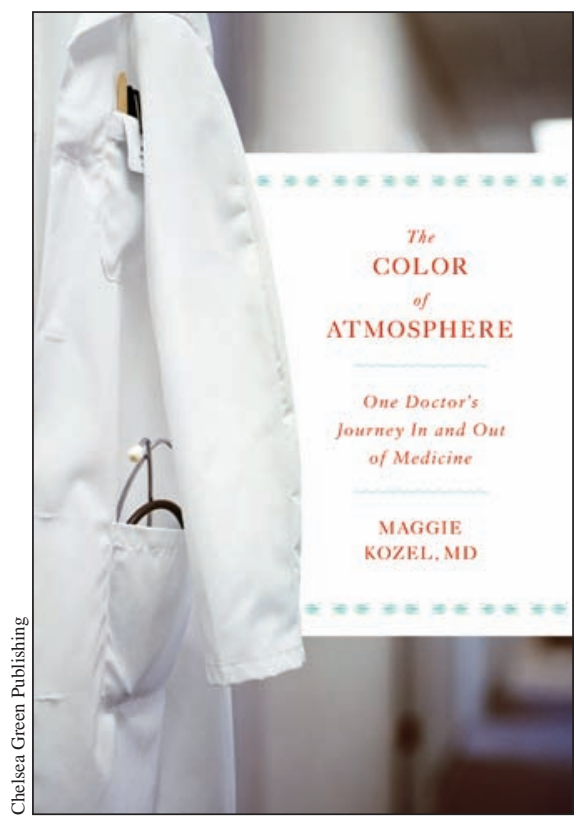

the bureaucracy of the insurance companies, the disparities in care for the poorer patients, the long hours and personal sacrifices associated with community practice, the entitlement of certain patients, and so on.

Many Canadian physicians will nod their heads in sympathy as they listen to Kozel's complaints: the details may be different, but we too might say that it's not medicine we get frustrated with, it's the system. Except that's too simple.

\section{It's not medicine we get frustrated with, it's the system.}

working as a generalist pediatrician in a community-based practice. During this time, she marries another physician and has two children. As the title implies, she eventually becomes disillusioned with medical practice and leaves to become a private school teacher (a career change made easier by the fact that she does not require additional training in education). She makes it clear that it was not medicine that she grew frustrated with, rather
Medicine is not, and never has been, solely an act of healing between a physician and a patient. Medicine is political, professional, systemic, cultural and institutional. Indeed, what distinguishes this book from many others written by physicians is that it does not simply focus on the clinical encounter without describing the context in which it takes place. Kozel presents us with a view into her practice which is authentic, plainly told, not sensa- tionalized. I have read a number of books written by American physicians, and this is the first one that left me feeling as though I really understood what it would be like to sit in the author's chair for a week. And to be honest, it makes me glad I am practising in Canada, although I recognize the author may not be the most unbiased source of information.

On the other hand, the very ordinariness of Kozel's practice means that The Color of Atmosphere is not like the books of Oliver Sacks or Harold Klawans where rare and exotic diseases lurk in every chapter. This is bound to be a disappointment for many doctors because, let's face it, most of us enjoy trying to spot a few zebras. Most of the time, Kozel herself finds her practice very routine and many doctors reading the book would probably agree with her, although general readers and medical students might find the clinical vignettes more novel and engaging. Neither is there a lot of deep reflection on the meaning and significance of medicine, although one can find other books that do that well. But reader beware: this is a book written by someone who left medicine, and as such it is not likely to recharge your batteries if you are feeling burnt out.

The Color of Atmosphere is wellwritten and accessible. Its chapters are quite short, making it easy for a busy doctor to read a chapter if he or she can find a minute to spare between all the things that demand time. Whether reading that chapter will make the doctor return to work with increased or diminished enthusiasm would be hard to say. But at least it provides a reality check regarding some of that greenerlooking grass south of the border.

\section{Lara Hazelton MD}

Psychiatrist

Halifax, NS

CMAJ 2012. DOI:10.1503/cmaj.120232 